\title{
The Role Of Integrity \& Hisbah In Acceleration Mechanism of Prevention and Corruption Eradication: An Islamic Accounting Perspective
}

\author{
Caturida Meiwanto Doktoralina ${ }^{1}$, Agusman Nurhidayat ${ }^{2}$, Fardinal $^{3}$, Irfan $^{4}$, Isnaini $^{5}$ \\ \{caturida_meiwanto_drm@mercubuana.ac.id ${ }^{1}$, agusmannurhidayat@mercubuana.ac.id², \\ fardinal@mercubuana.ac.id ${ }^{3}$, irfanumsu@gmail.com ${ }_{2}$ isnaini@uma.ac.id $\left.{ }^{5}\right\}$ \\ 1,2,3Fakultas Ekonomi dan Bisnis Universitas Mercu Buana, Jakarta Indonesia \\ ${ }^{4}$ Program Pascasarjana, Universitas Muhammadiyah Sumatera Utara, Medan, Indonesia \\ ${ }^{5}$ Post Graduate Studies, Universitas Medan Area, Medan, Indonesia
}

\begin{abstract}
Acceleration Mechanism of Prevention and Corruption Eradication (ACPE) needs quality Integrity and Hisbah. The studies provide the role of the IH Model in the ACPE in Indonesia. There are two research objectives; First, how to accelerate the IHModel tool based on the activities of potential primary sources of economic income in a region. Second, whether the role of the IH-Model has been carried out by the government through quality human resources and quality accounting reports. The methodology of these studies uses a literature review related to the IH-Model with secondary data, documentation and empirical studies. The result shows that the IH-Model has been carried out, but still needs a sustainable strategic stage, i.e. initial economic data collection and control of sustainable activities. The implications are to raise awareness in all levels of professions in accelerating the ACPE in Indonesia.
\end{abstract}

Keywords: Accountability, Government, Hisbah, Integrity, Potency.

\section{Introduction}

Actualise, the ACPE, requires the synergy of various elements of society with integrity. In addition, the community must also understand the purpose of hisbah in their daily lives. The corruption in generally occurs due to the deviation of responsibility and authority for personal interests and those closest to him by utilising public costs [1], [2]. Because the issue of corruption has become a public discussion in various countries, taking into account geopolitics and geo-strategies, the Government of the Republic of Indonesia established the Corruption Eradication Commission (KPK). KPK is mandated to eradicate corruption professionally, intensively, and continuously. Operationally the KPK has the areas of prevention, prosecution, information and data, as well as internal supervision and public complaints [3-5]. The aim is for the decision-makers and community at various levels to be aware of the negative impacts of corruption and to provide public understanding so that they can reduce the space/gaps in corruption in Indonesia. The presence of gaps in corruption can be seen from the report of the Indonesian Supreme Audit Institution's audit of local government financial reports (LGFR), regional governments in Indonesia still suffer from poor-quality financial reports. Furthermore, the audit detected 2,887 problems in controlling 
the implementation of the revenue and expenditure budget and 1,252 issues with internal control structures [6]. Thus, the quality of financial statements is not in line with expectations. The quality of financial accounting information refers to the information's qualitative characteristics [7], [8]. [9] stated that the quality of accounting information depends on its relevance, timeliness, accuracy, completeness and summarising.

KPK's independence is seen by not taking over the task of eradicating corruption from existing institutions. Therefore, the acceleration of ACPE to the community can run well. One of the ACPE programs to run well is through the recruitment of capable and integrated "Partners" in preventing corruption. The acceleration of the ACPE mechanism is needed because of the still high Corruption Perception Index (CPI) in Indonesia. In Years of 2018, Indonesia that is in the order of 89 out of 180, even there are many local leaders/other institutions/the private sector caught in corruption [10]. Therefore, the acceleration of the ACPE mechanism requires the synergy of selected community elements in each province who have an ideological, political, socio-cultural, economic, national defence and resilience understanding of diversity in Indonesia. One of the ways is through the limited recruitment of the KPK team. The synergy of the role of the community becomes essential because acts of corruption can spread and affect mental health at various levels of individuals, households and the welfare of citizens [11-15]. The acceleration of this program is expected to fill gaps and minimise the creation of corruption spaces [16]. In addition, this method can also reduce the upheaval of criminal acts of corruption against influential figures in their regions. The reason is that the 'informant' is a role model in the province.

Corruption in conventional accounting terms is known as fraud. Whereas Islamic makes the word of Allah SWT as the basis for an accountable record as sura al-Baqarah (2:188) i.e., "And do not consume one another's wealth unjustly or send it [in bribery] to the rulers in order that [they might aid] you [to] consume a portion of the wealth of the people in sin, while you know". Because of the large number of Muslims in Indonesia, it should be easy to realise the acceleration of the IH-Model ACPE mechanism in the life of the nation and state. Integrity in Islam means istiqamah, which is to hold fast to your stand to always obey Allah's commands, both in beliefs, words, and deeds [17-18] whereas hisbah as control of activities means religious responsibility which is based on telling the good and prevents rather than the enactment of lapses that can strengthen the implementation of regional financial management sourced from the natural wealth and resources of each province in Indonesia [19]. The challenge is that today, the majority of people have a capitalist mindset and mindset that is that individual success is paying attention to one's wealth and possessions.

Therefore, here is the accountants play an important role in ensuring the rationalisation of financial accountability reports. The importance of the accountant in the ACPE mechanism is because the accountant carries out the entire recording, classification and interpretation of the process of the transaction evidence provided. So, if the accountant applies the IH-Model in all structures correctly, then the decision making will also adjust the accountant's results. In the end, if this is carried out successfully, the government accounting system has systematically taken steps to prevent and eradicate corruption.

Factors of potential differences in regional income sources, regional autonomy regulation in political development, and constructive societal tendencies paying attention to the outcome of financial statements remain significant issues that require the role of the IH-Model. [20 23]. Transparency with the integrity and control of activities (hisbah) from external roles, namely the community, academics, and sustainable researchers is expected to have a successful effect on the acceleration of the ACPE mechanism, which if not implemented, can have a mistake on a decision [24-26]. The acceleration factor of the ACPE mechanism is also 
obliged to maximise the use of social media through the official website of each institution to neutralise developing issues. The use of social media is necessary to counter-effect negative information (hoaxes) that develops in society so that it does not provide room for the anticipation of perpetrators of criminal acts of corruption. The negative information that develops can be a favourable medium for informants who make a means of brief socialisation about the risk of corruption and a measure of the level of public concern for ACPE [27].

The IH-Model has been stated in the vision and mission of KPK. Where the KPK recruits elements of the nation, realising an Indonesia clean of corruption and implementing increased efficiency and effectiveness of law enforcement and reducing the level of corruption in Indonesia through coordination, supervision, monitoring, prevention, and enforcement with the participation of all elements of the nation [3]. However, the perception of 'capitalists' is slowly but surely beginning to move away from the 'morals' seen in the 'hedonic' lifestyle concept. The lifestyle in question is that that one's success can be seen from the level of the fortune. Therefore, the efficiency characteristics prioritised are effective in the KPK mission and Law No. 23/2014 not optimal yet. Therefore, in addition to the role of the media, the IHModel also requires the synergy of the elements of human resources of government officials, community leaders and traditional leaders, religious leaders and business leaders who dare to act honestly according to their duties and authorities. If whistleblowers are generally one of the best forms of action, which tend to be able to 'threaten' the life of the self and family of the reporter, then public education through ACPE acceleration that includes community leaders who adhere to the principle will be able to benefit the public good. The reason is that psychologically and religiously they are more courageous in conveying the truth. In addition, community leaders can also become a unifying bridge for the missionary information of the KPK in the early detection of abuse of authority in the regions.

Because corruption can affect the mental and socio-economic development of the community [29-30], an IH-Model study is needed. The problem is, First, how the IH-Model mechanism acceleration of the ACPE mechanism activities is taken out well. Second, Apakah The role of the IH-Model has been carried out with providing on the transparency of financial statements to the public. Indeed, this study has two main parts, namely, first, the factors that become the main need in improving the IH-Model of the acceleration of the ACPE mechanism and the need for recruitment of elements of the people who adhere to the principle. Second, explained the concept of IH-Model in the acceleration of the ACPE mechanism in Indonesia. So it appears that two priority cases must be emphasised - first, the mechanism for determining regional financial revenue potential. Second, the intensity and hisbah in the potential, HR management and reporting of regional finances.

\section{Acceleration Mechanism of Prevention and Corruption Eradication (ACPE) in Indonesia}

Urging the need for an accelerated ACPE mechanism in Indonesia because corruption was affecting the community in many ways even in the worst cases, costs of living. In short, this makes people lose freedom, health, or money. The costs of corruption can be divided into four main categories: political, economic, social and environmental. These four categories generally start from the potential for regional natural resource management and its utilisation. Law 23/2014 concerning Regional Government and Law 6/2014 concerning villages which in principle is to realise the ideals of independence based on the 1945 Constitution of the Republic of Indonesia. However, it has become a new "corruption" gap in the district which also makes the KPK's new attention to individual decision-makers to gain personal and group 
benefits [31]. In addition, this is because regional governments have considerable authority to regulate and manage their households autonomously, so one of the IH-Models in the development series is to include the roles of HR, Inspectorate, Prosecutors, Regional Police, DPRD and KPK too.

In some cases, the role of the Regional Financial Management Information System (SIPKD) can be minimising the space for corruption. However, there is a personal understanding of the perpetrators of corruption about the 'high political costs' can perhaps create there may be an 'agreement' among the decision-makers. The fact is that there are still provinces called 'champions of corruption', namely Aceh, North Sumatra, Riau, Banten, Papua and West Papua [32]. This case also explains that although an area already has a SIPKD as a regional government tool are still spaces in corruption that need to accelerate the ACPE programme with jointly of society. It also ensures that democracy \& bureaucracy are the tasks of workers who use technology, only to facilitate services and are not yet optimum to the 'moral-integrity' mechanism of workers and decision-makers [33-37]. Therefore, firmness, a synergy of the role of the central and regional governments are needed by providing legal sanctions against perpetrators and irregularities.

It is hoped that legal sanctions for irregularities (such as SIPKD user data entry) and responsible data bearers must be accelerated. The impact on the validity and reliability of the data, it is also a source of synergy in the same measure of potential natural resources and realisation. The need for information on the SIPKD data is also pressing because if it is not disclosed, it will cause "misguided thinking and perspective" of the community towards economic and social justice that is directly felt [38], [39]. Therefore, according to the 20152019 KPK Strategic Plan, the ACPE mechanism with the IH-Model is required to optimisation public information through technology and social media on the province/district government professionally. Also, it is necessary to recruit individuals who are moral and have strong integrity in developing the region.

\section{Integrity and Hisbah in the ACPE mechanism in Government Institutions in Indonesia}

Integrity was a necessary condition in the ACPE mechanism acceleration can have a positive influence on the community [41]. One of these positive influences is to promote a firm attitude to the stand between actions, values and principles [42]. In Islamic studies, Muhammad Syukri Salleh, (2000), (2003), (2008) states Muslims should pay attention to actions, values and principles that are mandatory horizontal human relations and natural resources (hablum minannas) and hablum minallah (the straight relationship between Allah SWT and humans). So that at its peak, humans can have social responsibility with integrity [46]. In addition to Integrity, another part needed to accelerate the ACPE mechanism is Hisbah. Hisbah is an essential element in managing Islam, as stated in Quranic Surah al-A'raf (7:157). Hisbah deductively plays a role as a monitoring system for institutions, organisations and individuals [47], [48]. Several studies on hisbah in management have been carried out in various organizations [49]. One of them is hisbah muttasib which is responsible for ensuring the rights of Allah SWT are fulfilled by Muslims who are under his care [50].

One of the concepts in Islam that teaches IH-Model reporting is through the quality of financial reporting as surah al-Baqarah, (2: 282). Therefore, SIPKD is not limited to financial data of the interests of the entity but also ensures that the entity operates sustainably in a 
divine bond that is achieving happiness, spiritual virtue and materiality [51]. The role of IHModel in SIPKD also supports the KPK's Vision, Mission and strategic planning (RENSTRA). Local governments complete data collection patterns holistically, integrally, systematically, objectively and positively in measuring input-process-output on natural resources, human resources obeying the principles of law in the region for the prosperity of the people [52]-[54] whereas the role of Institutions that are controlling the report of SIPKD ensures that all reports are qualified. Thus, if it goes well, the KPK has a role in ensuring qualified management has been carried out through eight internal strategic areas [40]. Therefore, the mechanism of hisbah that has been carried out by local governments is limited to audits of financial statements. However, in practice applications, there is still a lack of understanding of accounting records that adjust regional policies/regulations. For those reasons, the acceleration of the ACPE mechanism must include the KPK team and/or other elements of academics/practitioners. The purpose of involving a competent team is to prevent 'mistakes' or even 'irregularities' in the management of regional finances that will be made public. Besides, the ability of provincial HR/HR in the Inspectorate/ regional leadership also largely determines the success/failure of valid and reliable decision information.

Based on the description, the main thing that is of concern in strengthening the concept of the IH-Model is the need for human resources with strong capabilities and istiqomah in maintaining regional revenue and management potential. Religious leaders, traditional leaders, community leaders and academics who are concerned about the impact of corruption must be given priority facilities in the ACPE program. The priority is for the continuation of the character of the people who adhere to the principle. The socialization program will also be easily conveyed to the community who simultaneously include the ACPE-KPK team and regional government officials. Because if the concept only pays attention to the financial statements (output), then the gaps of corruption will still exist. Therefore, the concept of IHModel in Input-Process-Output in the Government must be implemented with one of them is to pay attention to the spiritual, social and cultural principles of the local community.

\section{Aim and Contribution of the Study}

The purposes of the proposed model study are to determine how the capabilities and relevance of establishing the IH-Model concept framework in Islamic Accounting Perspective, can identify the general concept of shariah accounting for further discussion to develop a persuasive model which can be tested again at an empirical study level (Figure 1). In addition, it can be followed by a discussion of the theoretical study that builds upon it.

\section{The Theoretical Model}

In the Quranic, explicitly, acts of corruption are not mentioned. However, some terms such as ghulul (defrauding), suht (bribery), al-sarq (stealing), hirabah (robbery) some of the terms are considered sufficient to represent the Qur'anic notion of corruption [55]. In the conventional view, [56] stated that the factors causing corruption were greed, opportunity, need, and disclosure. Where greed has the potential to be possessed by everyone and is related to individual corruptors. Possibility in committing fraud depends on the position of the perpetrators of the object of fraud.

Generally, the management of an organisation or company has more significant potential for cheating than employees. However, it should be underlined that the opportunity to commit fraud will always be at every level of the position. The Exposure of fraud in an 
institution does not guarantee the repeat of the fraud. Therefore, every perpetrator of fraud should be subject to sanctions if his actions are revealed. In the case of individuals, the perpetrators of fraud consisting of Greed usually associated with individual morals and the environment. High living needs can change someone's view related to assets owned by the institution where he works. Even the pressure faced at work can also cause honest people to have a motive for cheating.

\section{Discussion}

In this modern era, studying changes in behaviour is important for decision-makers, accounting information supervisors, and policymakers. It discusses the potential of technological changes in financial reporting, external audit, and management accounting, taking into consideration potential changes in the future of accounting and auditing research [57]. Even the community as taxpayers have a portion as external control of the policies implemented by the government.

The Government Regulation Republic of Indonesia Number 65 explained the obligation of information technology utilisation. Therefore, most of the Accounting Information System (AIS) has been developed until now in helping to provide correct information [59], [60]. However, culture, staff development and knowledge in the management control system design are also important to direct accountants in committing to provide relevant information to make better decisions [61]. Potential Regional Income is an important initial source of financial information in every region in Indonesia. Therefore, the use of information technology affects the quality of accounting information, as does the application of good governance principles [62]. The Government Regulation Republic of Indonesia Number 65 explained the obligation of information technology utilisation.

The Government Regulation Republic of Indonesia (PP) Number 101 defined good governance as governance that develops and applies the principles of professionalism, accountability, transparency, excellent service, democracy, efficiency, effectiveness and supremacy and can be accepted by the community as a whole. Although the role of the IHModel has been carried out by the government through qualified human resources and accounting reports, not all are open to the public [64], [65]. Therefore, AIS is expected to provide transparency in accounting and services in the government sector and assist the role of Integrity \& Hisbah in Acceleration Mechanism of Prevention and Corruption Eradication [66].

The first stage in the process of accelerating the role of the IH-Model to be fundamental is to get certain information about the main sources of potential economic income in a region. If in general, due to systemic reasons, the use of technology must be carried out in the structural and functional sectors of government. The structural and functional sectoral government must be integrated from the lowest level of government to the central government. Besides, the data obtained must be published to the public. If this has been done, the community can also directly become a tool of control by utilizing openness to public information. The second stage is to have obtained the economic information; the draft budget provision is appropriate. In addition, the use will also have a social impact on society. The reason is that the public will continue to exercise control over the activities carried out by the public policy official. Stage 3, i.e. will provide administrative transparency regarding Disbursement of Funds Letters, Payment Request Letters and Government Letters of Disbursement of Funds that are routinely carried out by Local Governments.

The role of transparency public starting from the start of data collection information on the initial income of a region's economy, the determination of the acquisition of regional funds 
to the interests of administration will certainly have a positive impact on the accountability of a local government.

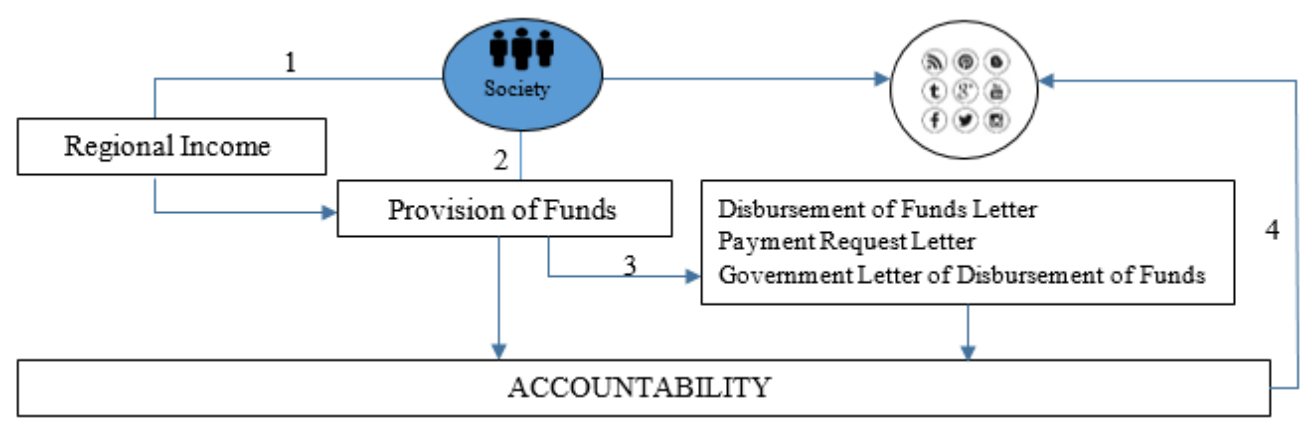

Fig.1. The Concept of IH-Model in ACPE on SIPKD

\section{Conclusions}

KPK has implemented the IH-Model mechanism through a sustainable work program. The form of support is through the implementation of the RENSTRA and ACPE programs in a professional manner. The acceleration of the ACPE mechanism has greatly assisted local governments in accelerating development and improving socio-economic development. However, the main factor of concern the IH-Model in the acceleration of the ACPE mechanism because of the real data on the potential of natural resources and other resources not yet all mentioned in the regional revenue design or the financial statements. Actual data on natural and other potential resources is necessary because the concept of regional growth depends on the level of regional financial revenue and will affect the data source of the Central Government. Also, local governments must implement accounting principles well that can be traced by the public in the IPO process more widely.

The IH model is implemented by dividing the proportion of work that can increase regional gross domestic product (GDP). However, support for the role of law-abiding people is needed. The part of the community must comprise all levels of the structure to be achieved in economic improvement and regional development. The need for the validity of the potential of natural resource data, the availability of qualified human resources is urgent. Quality internal and external accounting management in SIPKD is needed to provide information for people's welfare. The main objective of this research is to maintain the country's practical framework through the elements of society that there is to the principles and continue to carry out understanding and dissemination of ACPE. The implications of applying the IH Model can give the impression of awareness at all levels of elements and professions in Indonesia.

Acknowledgements. We wish to thank the Government of the Republic of Indonesia, the Corruption Eradication Commission, the Police of the Republic of Indonesia, Indonesian Supreme Audit Institution, State Development Audit Agency, regional Inspectorate and Financial Transaction Reports and Analysis Center, who continuously maintains the principles of compliance in the Republic of Indonesia. We also wish to express our appreciation to the Head of research centre, Dean of Economics \& Business Faculty \& Head of Accounting 
Programme of Mercu Buana University which has been very constructive at various stages in the development of this article.

\section{References}

[1] Transparency International, "What is corruption?," 2019. [Online]. Available: https://www.transparency.org/what-is-corruption\#define. [Accessed: 22-Jun-2019].

[2] C. J. Friedrich, "Corruption concepts in historical perspective," in Political Corruption, Routledge, 2017, pp. 15-24.

[3] Komisi Pemberantasan Korupsi, "Sekilas KPK," kpk.go.id, 2017. [Online]. Available: https://www.kpk.go.id/id/tentang-kpk/sekilas-komisi-pemberantasan-korupsi. [Accessed: 22-Jun-2019].

[4] Republik Indonesia, "Undang-Undang Nomor 30 Tentang Komisi Pemberantasan Tindak Pidana Korupsi," 2002.

[5] A. Jamil and C. M. Doktoralina, "The Save KPK Movement: A Framing Analysis of Coverage in Indonesian News Media Surrounding the KPK and Police Dispute," Mediterr. J. Soc. Sci., vol. 7, no. 3S1, pp. 229-237, 2016.

[6] Indonesian Supreme Audit Institution, Ikhtisar Hasil Pemeriksaan Semester I. Jakarta, Indonesia, 2018.

[7] D. W. Kieso, J. J. Weygandt, D. E. Kieso, and P. D. Kimmel, Study Guide to Accompany Financial Accounting, 8e. John Wiley \& Sons, 2012.

[8] D. E. Kieso, J. J. Weygandt, and T. D. Warfield, Intermediate Accounting, Working Papers, vol. 2. John Wiley \& Sons, 2011.

[9] J. A. Hall, Accounting information systems. Cengage Learning, 2012.

[10] databoks.katadata.co.id, "Indeks Persepsi Korupsi Indonesia 2018 Naik Jadi 38 Poin," 30 Januari 2019, 2019. .

[11] E. Tiongson, H. Davoodi, and S. Gupta, "Corruption and the provision of health care and education services," in The Political Economy of Corruption, Routledge, 2002, pp. $123-153$

[12] M.-H. Lee and M.-C. Lio, "The impact of information and communication technology on public governance and corruption in China," Inf. Dev., vol. 32, no. 2, pp. 127-141, 2016.

[13] M. Lewis, "Governance and corruption in public health care systems," Cent. Glob. Dev. Work. Pap., no. 78, 2006.

[14] B. McPake et al., "Informal economic activities of public health workers in Uganda: implications for quality and accessibility of care," Soc. Sci. Med., vol. 49, no. 7, pp. 849-865, 1999.

[15] A. Sundström, "Understanding illegality and corruption in forest governance," $J$. Environ. Manage., vol. 181, pp. 779-790, 2016.

[16] T. Vian, "Review of corruption in the health sector: Theory, methods and interventions," Health Policy Plan., vol. 23, no. 2, pp. 83-94, 2008.

[17] A. Al-Qurtubiy, “Al-Jami“ li Ahkam al-Qur'an.” Dar al-Kutub al-'Ilmiyyah, Beirut, Lubnan, 1993.

[18] S. I. Al-Qurthubi, Tafsir Al-Qurthubi. Pustaka Azzam, 2007.

[19] N. Puspasari and E. Suwardi, "Pengaruh Moralitas Individu Dan Pengendalian Internal Terhadap Kecenderungan Kecurangan Akuntansi: Studi Eksperimen Pada Konteks Pemerintahan Daerah,” Simp. Nas. Akunt., vol. 15, 2012. 
[20] D. Harianto and P. H. Adi, "Hubungan antara dana alokasi umum, belanja modal, pendapatan asli daerah dan pendapatan per kapita," Simp. Nas. Akunt. X, pp. 26-28, 2007.

[21] I. Wahyudi, "Analisis Faktor-Faktor Yang Mempengaruhi Korupsi Anggaran Pendapatan Belanja Daerah (APBD) Di Malang Raya," Penelit. Univ. Muhammadiyah Gresik, 2010.

[22] T. Kurniawan, "Peranan Akuntabilitas Publik dan Partisipasi Masyarakat dalam Pemberantasan Korupsi di Pemerintahan,” Bisnis Birokrasi J., vol. 16, no. 2, 2011.

[23] I. Bastian, Akuntansi sektor publik. Universitas Terbuka, 2014.

[24] M. R. Hartono, "Tinjauan Yuridis Normatif Peran KPK dalam Mencegah Tindak Pidana Korupsi," J. LEX Spec., no. 21, pp. 58-73, 2017.

[25] E. Nugroho, "Pemanfaatan teknologi informasi dalam rangka memberantas tindak pidana korupsi secara elektronik," J. Din. Huk., vol. 14, no. 3, pp. 539-546, 2014.

[26] D. N. S. Wiranta, "Transformasi Birokrasi: Cara untuk penguatan etika dan integritas dalam pencegahan korupsi," J. Lingk. Widyaiswara, vol. 2, no. 4, pp. 44-71, 2015.

[27] C. C. Arthur Shacklock, Charles Sampford, Measuring Corruption, 1st Editio. London: Routledge, Taylor \& Francis Group, 2006.

[28] Republik Indonesia, "Undang-Undang Nomor 23 Tentang Pemerintahan Daerah," 2014.

[29] M. U. Chapra, The future of economics: An Islamic perspective, vol. 21. The Islamic Foundation Leicester, 2016.

[30] D. H. Ma'u, "Korupsi Kolusi dan Nepotisme dalam Perspektif Hukum Islam,” J. Ilm. Al-Syir'ah, vol. 2, no. 1, 2016.

[31] A. V Banerjee, “A theory of misgovernance," Q. J. Econ., vol. 112, no. 4, pp. 1289$1332,1997$.

[32] D. B. Raharjo, "KPK Sebut Enam Provinsi di Indonesia Ini Juara Korupsi,” 2019. [Online]. Available: https://jateng.suara.com/read/2019/04/10/212117/kpk-sebut-enamprovinsi-di-indonesia-ini-juara-korupsi. [Accessed: 21-Jun-2019].

[33] M. Philp, "Conceptualizing political corruption," in Political Corruption, Routledge, 2017, pp. 41-58.

[34] I. Kolstad and A. Wiig, "Does democracy reduce corruption?," Democratization, vol. 23, no. 7, pp. 1198-1215, 2016.

[35] F. J. Goodnow, Politics and administration: A study in government. Routledge, 2017.

[36] S. Rose-Ackerman and B. J. Palifka, Corruption and government: Causes, consequences, and reform. Cambridge university press, 2016.

[37] Tranparency International, “Access to Information," 2019. [Online]. Available: https://www.transparency.org/topic/detail/accesstoinformation. [Accessed: 21-Jun2019].

[38] R. K. Adi, "Penataan Tanah Berbasis Masyarakat Dalam Menunjang Sistem dan Usaha Agribisnis di Indonesia,” SEPA J. Sos. Ekon. Pertan. dan Agribisnis, vol. 11, no. 1, pp. 66-78, 2017.

[39] Worldbank, Competitive Advantage Increase. 2018.

[40] Komisi Pemberantasan Korupsi, “Renstra KPK Tahun 2015-2019.” p. 34, 2015.

[41] S. A. Schutte, "Again The Odds: ANti-Corruption Reform in Indonesia," Public Adm. Dev., vol. 32, pp. 38-48, 2012.

[42] A. Harefa, Membangkitkan Etos Profesionalisme. Jakarta, Indonesia: Gramedia Pustaka Utama, 2004.

[43] Muhammad Syukri Salleh, "Ke arah pengurusan pembangunan Islam," in Seminar 
Pengurusan Pembangunan Islam, Universiti Sains Malaysia, 2000.

[44] Muhammad Syukri Salleh, Tujuh prinsip pembangunan berteraskan Islam. Zabra Editions Sdn. Bhd., 2003.

[45] Muhammad Syukri Salleh, "ISDEV Paper Series--Islamic Development Management: Three Fundamental Questions," Pulau Pinang Pus. Kaji. Pengur. Pembang. Islam (ISDEV), Univ. Sains Malaysia, 2008.

[46] M. Rodriguez-Fernandez, "Social responsibility and financial performance: The role of good corporate governance," BRQ Bus. Res. Q., vol. 19, no. 2, pp. 137-151, 2016.

[47] A. H. Abdullah, Hisbah dan pentadbiran negara. IKDAS, 2000.

[48] M. Makhsin, Hisbah: sistem pengawasan dan etika pengurusan Islam. UUM Press, 2008.

[49] A. Ibrahim, "Jurnal Islam dan Masyarakat Kontemporari," J. Islam dan Masy. Kontemporari, vol. 1, no. 11, pp. 26-39, 2015.

[50] Z. Mamat, "Institusi Hisbah dan Peranannya dalam Mengawal Kegiatan Ekonomi Negara Islam,” J. Muamalat, vol. 3, pp. 113-138, 2010.

[51] I. Triyuwono, Akuntansi Syariah: Perspektif, Metodologi dan Teori, Edisi kedu. Indonesia: PT RajaGrafindo Persada, 2012.

[52] H. Mulyono, Supriharsanto, L. Sianipar, S. Sutaat, M. N. Madjid, and Miyasto, Bidang Studi Geostrategi Indonesia dan Ketahanan Nasional, 2nd, Lemhann ed. Jakarta Indonesia: Lembaga Ketahanan Nasional Republik Indonesia, 2017.

[53] S. Tjakrawerdaya, S. Soedarno, P. S. Lenggono, B. Purwandaya, M. Karim, and L. A. Salim, Sistem Ekonomi Pancasila, Kedua. Raja Grafindo Persada, 2017.

[54] S. Yasni, Karsiyanto, Kisnu Haryo, E. Tanjung, S. Remon, and R. Semendawai, Materi Pokok Bidang Studi Politik, Pertama. Lembaga Ketahanan Nasional Republik Indonesia, 2017.

[55] B. Birahmat, "Korupsi dalam Perspektif Alquran," FOKUS J. Kaji. Keislam. dan Kemasyarakatan, vol. 3, no. 1, p. 65, 2018.

[56] T. W. Singleton, A. J. Singleton, G. J. Bologna, and R. J. Lindquist, Fraud Auditing and Forensic Accounting, 3rd (Third. John Wiley \& Sons, 2006.

[57] V. Arnold, "The changing technological environment and the future of behavioural research in accounting," Account. Financ., vol. 58, no. 2, pp. 315-339, 2018.

[58] The Government Regulation Number 65 Republic of Indonesia, Amendement to Government Regulation Number 56 Of 2005 Concering Regional Financial Information Systems. 2010, p. 4.

[59] C. M. Doktoralina and Z. Bahari, "Zakat Accounting Information System in Private Higher Education,” Eur. Res. Stud. J., vol. XXI, no. 3, pp. 1-14, 2018.

[60] A. M. A. Alrabei, "The impact of accounting information system on the Islamic Banks of Jordan: an empirical study," Eur. Sci. Journal, ESJ, vol. 10, no. 4, pp. 184-198, 2014.

[61] I. Grabner and G. Speckbacher, "The cost of creativity: A control perspective," Accounting, Organ. Soc., vol. 48, pp. 31-42, 2016.

[62] H. Setiyawati and C. M. Doktoralina, "The importance of quality accounting information management in regional governments in Indonesia," Manag. Sci. Lett., vol. 9, pp. 2083-2092, 2019.

[63] The Government Regulation 101, Republic of Indonesia. 2000, p. 18.

[64] C. Brewster and M. Söderström, "Human resources and line management 1," in Policy and practice in European human resource management, Routledge, 2017, pp. 51-67.

[65] T. Suryanto, E. J. Thalassinos, and I. E. Thalassinos, "Board Characteristics, Audit 
Committee and Audit Quality: The Case of Indonesia," Int. J. Econ. Bus. Adm., vol. 5, no. 3, pp. 47-57, 2017.

[66] S. Mulyani, L. Suzan, Y. Dagara, E. Yuniarti, M. Alam, and others, Sistem Informasi Akuntansi: Aplikasi Di Sektor Publik: Panduan Praktis Analisis dan Perancangan Implementasi SIA di Sektor Publik. Unpad Press, 2019. 